\title{
O FORRÓ “PÉ DE SERRA” E A MOTIVAÇÃO DOS JOVENS FORROZEIROS DE BELO HORIZONTE
}

Recebido em: 20/04/2011

Aceito em: 01/04/2012

\author{
Camila Moura Cardilo ${ }^{1}$ \\ Pontifícia Universidade Católica de Minas Gerais- PUC Minas \\ Belo Horizonte - MG - Brasil
}

RESUMO: O forró "Pé de Serra" contagia muitos jovens da cidade de Belo Horizonte. Assim, este estudo procura compreender o motivo que os levam a viver e reviver esta dança, música e espaço definido como forró. Primeiramente foi realizada uma pesquisa bibliográfica para apresentar o significado do forró "Pé de Serra", do jovem e da motivação. Posteriormente, uma observação em um dos espaços da cidade em que se realiza o forró e uma aplicação de questionários a 20 jovens freqüentadores, deu continuidade à pesquisa. Quanto aos resultados verificou-se que, mesmo com as influencias externas do meio, os jovens possuem um forte envolvimento intrínseco com o forró pelo forte despertar de sentimentos e emoções.

PALAVRAS-CHAVE: Dança. Atividades de Lazer. Recreação.

\section{THE FORRÓ “PÉ DE SERRA” AND THE MOTIVATION OF BELO HORIZONTE'S YOUNG FORROZEIROS}

ABSTRACT: Forró "Pé de Serra" to infects many young city of Belo Horizonte. So, the study seekes to understand the reason that the lead is to live end living again to dance, to music and space defined forró. Was first conducted a bibliographic search to present the meaning of forró "Pé de Serra," young, and motivation. Posterialy, an observation spaces in a city where takes place forró and application of questionnaire to 20 young goers, has continured research. How the results there was that, same with influences the external environment, young have a strong involvement intrinsic with forró wake of the strong feelings and emotions.

KEYWORDS: Dancing. Leisure Activities. Recreation.

\section{INTRODUÇÃO}

A vida nos oferece vários caminhos a serem trilhados... e o homem, como sujeito

\footnotetext{
${ }^{1}$ Bacharel em Educação Física pela PUC- Minas.
} 
da incompletude, se vê repleto de buscas. Buscamos a realização, no trabalho, no estudo, no sucesso, nos amigos, na família, na felicidade e inevitavelmente no prazer! São inúmeros os motivos pelos quais o ser humano busca algo em sua vida, mas nem sempre esses são comuns a todos, pois cada um possui seus desejos, ideais, concepções, percepções, conhecimentos que se expandem e expressam de forma específica. .

Há aproximadamente oito anos, o forró "Pé de Serra"² se tornou uma prática essencial em minha vida, manifestação que considero uma das minhas fontes para a busca do lazer e do prazer. Deparei-me com essa modalidade na escola, quando estava na $6^{\text {a }}$ série do ensino fundamental. Curiosamente, não foi nas aulas de Educação Física que esse interesse surgiu, e sim, durante alguns recreios. Nesses momentos, tocava-se nas caixas de som dispostas pelo pátio, o forró "Pé de Serra". Os alunos e alunas cantavam e dançavam, eu apenas observava. O forró vivia seu momento de explosão, um verdadeiro auge entre os hits da época. Valeria a pena problematizar seu uso pela direção da escola: seria para controlar os ânimos dos adolescentes? Seria para educá-los para uma prática de lazer? Esse não é o objetivo desse trabalho, mas posso dizer o que aconteceu comigo. Eu não dominava a dança, portanto não a praticava, o que realmente intimidava-me. Mesmo assim, fui desenvolvendo meu gosto pelo forró. Passei a treinar passos em casa, sozinha, ouvindo meu primeiro CD de forró, dado pela minha mãe.

Tempos depois, conheci uma pessoa que se tornou minha amiga, com quem dividi o gosto pelo forró "Pé de Serra". Já em idade de freqüentar o "forró" (modo carinhoso de denominar o forró "Pé de Serra”, chamado assim pelos seus apreciadores), eu e minha amiga fomos pela primeira vez. Nesse dia tivemos nosso primeiro contato

\footnotetext{
2 Dança e música que se inspiram no universo rural sertanejo, nascida por volta de 1940 no Nordeste brasileiro (JUNIOR; VOLP, 2005).
} 
com os forrozeiros(as) de Belo Horizonte. Tudo era fantástico: ritmo, letra, dança; encantava-me e me transportava para outro mundo (HUIZINGA, 2001). Na batida do forró, o meu coração também batia mais forte, a felicidade tomava conta da minha alma, o meu corpo falava. Ainda hoje, freqüento casas noturnas para desfrutar do prazer de dançar e escutar o forró.

A dança do forró "Pé de Serra" traz consigo além de uma grande história, também valores e realidades proporcionando possibilidades de compreendê-la como uma fonte educativa que desenvolve conhecimento, sociabilidade e prazer. O ritmo é contagiante, forte e marcante. A letra da música retrata a realidade nordestina destacando o amor e a relação do clima árido e seco de sua natureza. A dança é alegre, realizada em pares, com a condução do cavalheiro (cabe à dama entregar-se a ele e seguir seus comandos), passos específicos (lentos ou rápidos) conforme o ritmo, onde o contato com o outro envolve respeito, atenção e sintonia. Portanto, vivenciar o forró, torna-se uma possibilidade de nos educarmos para e pelo lazer (MARCELLINO, 1987).

O surgimento do forró na Região Sudeste e, consequentemente na cidade de Belo Horizonte, propagou-se entre os jovens e trouxe-lhes uma cultura distinta, uma vivência diferente. Dele faz parte costumes, roupas, calçados, acessórios, música e dança bem características da Região nordestina. Com o encanto dos jovens belorizontinos, a prática do forró "Pé de Serra" espalhou-se e até os dias atuais abrange um público bem significativo de praticantes, seja em casas noturnas, escolas de dança ou num encontro entre amigos.

Segundo Lancellotti (1992, p.14), "ser jovem é ser e ter um modo próprio de prazer." O jovem que busca o forró, identifica-se com a prática por motivos específicos, fazendo-o sentir prazer em viver e ainda querer reviver estes momentos. A minha 
hipótese é de que alguns se encontram no forró pela valorização cultural e sentimento emotivo que os envolvem na dança, outros em busca de amizade ou relacionamentos, e alguns são influenciados por outras pessoas ou por não terem "nada melhor pra fazer".

O que me move nesse estudo é desvendar o mistério que envolve os jovens forrozeiros, tentando compreender o que os motivam a viver e reviver o forró "Pé de Serra", tudo isso considerando que, o forró é uma possibilidade de socialização, interação e integração do jovem com outro jovem, com o ambiente e consigo mesmo. Assim, essa prática seria um meio do jovem sentir o prazer envolvendo-se culturalmente numa manifestação educativa, rica, alternativa, lúdica e repleta de emoções. Nesse contexto, o objetivo desse estudo, foi verificar qual a motivação dos jovens para vivenciar o forró "Pé de Serra". Parti do significado do forró para cada um deles e questionei o que os movem a viver e reviver a dança, a música e o ritmo.

Para a realização desse trabalho foi utilizada uma metodologia qualitativa, com o objetivo de trabalhar com os aspectos que não podem ser quantificados, focando na compreensão e na explicação da dinâmica das relações sociais (FONSECA, 2002). Para dar início ao estudo, foi realizada uma pesquisa bibliográfica para a compreensão do forró "Pé de Serra", do jovem e da motivação. Posteriormente, uma pesquisa de campo numa casa noturna de Belo Horizonte, deu continuidade ao trabalho. Essa investigação aconteceu em um dia da semana que houve especificamente o forró "Pé de Serra". Nessa pesquisa, foi observado o espaço e também o comportamento dos jovens ali presentes. Além disso, foram aplicados questionários, como instrumento de coleta de dados. Os mesmos foram respondidos por 20 jovens (10 mulheres e 10 homens) escolhidos de forma aleatória, com a restrição de terem no mínimo 18 e no máximo 35 anos de idade. 


\section{O FORRó, O JOVEM E A MOTIVAÇÃO NO MEIO SÓCIO HISTÓRICO CULTURAL}

No presente item, o objetivo é apresentar o significado do Forró "Pé de Serra", do jovem e da motivação no meio sócio histórico cultural. O referencial teórico aqui discutido, possibilitará a análise dos motivos que levam o jovem a vivenciar o forró "Pé de Serra".

\section{O forró “Pé de Serra”...}

O forró "Pé de Serra" remete a um ritmo de música e dança de origem nordestina, denominado "Forró de Raiz", é uma expressão cultural tradicional que gerou outras possibilidades para essa modalidade em todo país. O nordestino é o sertanejo que convive com a seca, a fome, a miséria, mas que busca alegria na sua cultura, na dança e na música.

Analisando as pesquisas sobre a temática, percebe-se, que a palavra "forró" ainda não possui um significado bem definido. Segundo Expedito Leandro Silva (2003) a origem do termo forró possui duas versões: a primeira vem da expressão for all, que significa "para todos" e era usada como convite aberto para quem quisesse participar das festas que os ingleses ofereciam para os operários que trabalhavam na construção das estradas de ferro. Já a segunda versão vem da palavra forrobodó, que era utilizada para referir a um baile comum e sem etiqueta. O "Pé de Serra", geograficamente, referia-se à posição de casas construídas ao pé da colina. A partir daí, surgiu à denominação do forró "Pé de Serra", que eram as festas realizadas no campo ao som do forró nordestino.

Na construção e trajetória do forró "Pé de Serra" percebe-se uma mistura de 
ritmos: xote, baião, coco, xaxado, maracatu, capoeira... isso aconteceu, devido a sua relação e mistura com outras culturas brasileiras. Segundo Junior, Fontes e Dias (2009, p.244),

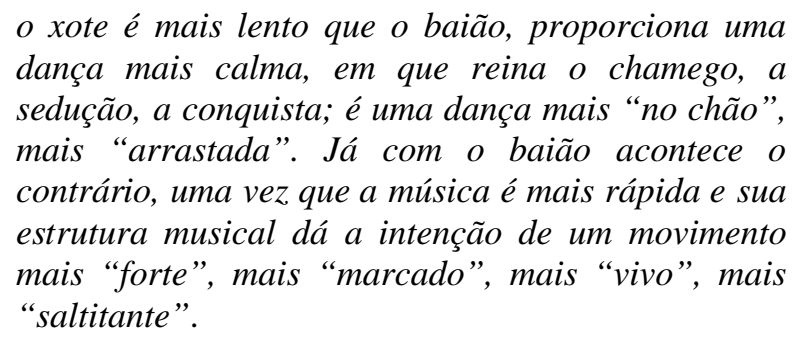

Segundo Cortês (2000), o coco vem de origem negra, é dançado em roda, geralmente em pares e acompanhados de palmas e sapateados. O xaxado, também dançado em círculo apenas por cangaceiros, logo depois se transformou no baião e consequentemente permitiu a participação feminina. O maracatu era um cortejo de negros no período colonial, dançado ao final de cerimônias religiosas, ao som de batuques. A capoeira, aparece como dança, luta ou jogo que executam movimentos que imitam os animais.

Com a participação de outros ritmos na trajetória do forró, percebe-se que essas misturas culturais são encontradas nas letras das músicas, no "gingado" da dança e nos instrumentos. Assim, o forró passou e ainda passa por constantes transformações, seja no passo da dança, no ritmo ou nas letras musicais.

Os instrumentos básicos utilizados pelos trios ou cantores(as), desde sempre, são a sanfona, a zabumba e o triângulo. Eles cantam letras musicais que, em sua maioria, caracterizam o ambiente rural do homem sertanejo (SILVA, 2003), como: Súplica

\section{Cearense.}


Oh! Deus, perdoe este pobre coitado

Que de joelhos rezou um bocado

Pedindo pra chuva cair sem parar

Oh! Deus, será que o senhor se zangou

E só por isso o sol se arretirou

Fazendo cair toda chuva que há

Senhor, eu pedi para o sol se esconder um tiquinho

Pedir pra chover, mas chover de mansinho

Pra ver se nascia uma planta no chão

Meu Deus, se eu não rezei direito o Senhor me perdoe,

$\mathrm{Eu}$ acho que a culpa foi

Desse pobre que nem sabe fazer oração

Meu Deus, perdoe eu encher os meus olhos de água

E ter-lhe pedido cheinho de mágoa

Pro sol inclemente se arretirar

Desculpe eu pedir a toda hora pra chegar o inverno

Desculpe eu pedir para acabar com o inferno

Que sempre queimou o meu Ceará (GONZAGA, 2005).

O forró já se fazia presente em algumas regiões do Brasil, mas foi em 1940 que ele surgiu no mercado fonográfico na voz de Luiz Gonzaga, que o apelidou inicialmente de "baião". Isso lhe rendeu, anos mais tarde, o titulo de Rei do baião. Como dança popular, o baião foi muito apreciado durante o século XIX no Nordeste brasileiro. "Em 1944, o baião foi modificado por Luiz Gonzaga alcançando o sucesso nacional" (DREYFUS ${ }^{3}$ apud SILVA, 2003, p. 82). Como ele afirma numa de suas canções: "Eu já dancei balancê/ chamego, samba e xerém/ mas o baião tem um quê/ que as outras danças não têm” (TEIXEIRA; GONZAGA, 1949).

Na década de 1940, o desenvolvimento industrial na região Sudeste também contribuiu para o crescimento do gênero musical, pois ocasionou um movimento migratório dos nordestinos para essa terra que apresentava progressão socioeconômica, sendo que o Nordeste passava por problemas, como: constantes secas, desigualdade social e domínio do coronelismo e grandes latifúndios (SANTOS, 2004). Com isso, Luiz Gonzaga e outros cantores tinham o privilégio de reconstruir o ambiente social do

\footnotetext{
${ }^{3}$ DREYFUS, D. Vida do Viajante: a saga de Luiz Gonzaga. São Paulo: Editora 34, 1996.
} 
nordestino (SILVA, 2003). Algumas músicas "cantam" a saudade do migrante nordestino por sua terra (Jerimum de Gogo).

\author{
Ai, tô doidinha pra ver \\ O meu velho nordeste, \\ sertão e agreste \\ Onde eu hei de morrer \\ Ai, que saudade que dá \\ Quando ouço um baião \\ Sinto o meu coração \\ Só querendo parar \\ Eu vou voltá pra lá.. \\ Eu vou voltá pra lá... \\ Eu vou voltá pra lá... \\ Eu vou voltá pra lá... \\ Será, será? \\ Que mamãe vai me abençoar \\ Será, será? \\ Que eu encontro \\ O que deixei por lá \\ Saí do nordeste \\ Deixei meu xodó \\ Andei pelo mundo \\ Que nem "caracó"...(SILVA; AQUINO, 1964)
}

O migrante nordestino trouxe com ele, para a região Sudeste, sua cultura no qual forró é parte integrante, e, com certeza, contribuiu para que este permanecesse presente até os dias atuais. Tornou-se um lazer para aqueles que não o conhecia, uma novidade de música, dança, acessórios e vestimentas. Desse modo, os nordestinos revivem o que deixaram para trás, explicitam a saudade da terra natal e mantém vivo suas questões identitárias.

Na década de 1950, no auge da Rádio nacional, o baião tem seu sucesso propagado e surge a participação da mídia. O baião de Luiz Gonzaga é tocado em clubes, cinemas e programas de rádio. Ele faz a adaptação do ritmo de acordo com o perfil urbano da sociedade, além de entregar suas canções a outros intérpretes. Mais tarde, o cantor que iniciou seu trabalho no Nordeste é reconhecido nacionalmente e sua música começa a ser reconhecida e tocada em todo Brasil. Porém, no final da década de 
1960 novos compositores surgem na música brasileira, adotando motivos coerentes com a realidade vivida naquele momento, contribuindo com o surgimento de outros gêneros musicais. È o caso da bossa nova, a jovem guarda e um pouco mais tarde, o movimento que foi denominado Tropicália. O baião entra em decadência.

Por volta de 1967-1968, Luiz Gonzaga passa a utilizar o termo "forró", assim o baião passa a ser um dos ritmos que compõe o forró "Pé de Serra". A inovação da música e dança, ganha alterações na batida da zabumba, na linguagem e no ritmo (SILVA, 2003) e faz com que, na década de 1970, o forró volte aos meios de comunicação de massa, inauguram-se às primeiras casas em São Paulo e no Rio de Janeiro. Além disso, essas cidades estão com um número elevado de migrantes nordestinos. Assim, surgem novos artistas do gênero, também nordestinos presentes nestas cidades, como: Alceu Valença, Zé Ramalho, Elba Ramalho... (ALFONSI, 2007) possibilitando a diversidade cultural entre os artistas brasileiros.

Em 1990 o forró passa por novas mudanças, surge o forró universitário, assim chamado por ter "nascido de um movimento empreendido por estudantes universitários" (ALFONSI, 2007, p.44). Esse forró torna-se diferente e influenciado por outros ritmos musicais como o Rock`n Roll, o Samba, o Funk e o Reggae, nas décadas de 1990/2000 (JUNIOR; VOLP, 2005). A letra a seguir mostra claramente essa influência (Inovação).

\author{
Não sei de nada \\ Sou um eterno aprendiz \\ O som que agrada amigo \\ É você quem diz \\ E eu assumo agora \\ Tudo que eu fiz foi só \\ Que esse som é diferente eu sei \\ Eu não fiz nada amigo \\ Eu só inovei \\ Estakazero amigo \\ Esse é o meu forró
}


Meu Bob Marley se chamava Luíz

Não era o rei do reggae

E sim do baião

Minha Jamaica

É o nordeste é o sertão

É o som da terra

Reggae o pé da serra

Que nasce o forró

Forró pesado xote colado

E a menina na ponta do pé

É que eu te carregue

Forró com reggae

É que faz a poeira subir... (MALINO, 2005)

Com isso, o forró ganhou novas características, o passo com marcação atrás, variações e giros executado tanto pela dama quanto pelo cavalheiro (TRINDADE ${ }^{4}$ apud JUNIOR; VOLP, 2005). Portanto, percebe-se que o forró universitário trouxe novas características para o forró "Pé de Serra". Entretanto, essa nomenclatura caiu em desuso entre os dançantes do forró, uma vez que ele não é dançado e nem faz parte unicamente da cultura de estudantes das Universidades.

No período de 2000 a 2002, cresce o número de trios e bandas de forró. Eles tocavam em várias cidades do Sul e Sudeste brasileiro, ocorre abertura de novas casas dedicadas especificamente ao forró ou a inclusão na programação de casas noturnas de um dia dedicado ao mesmo. "O boom dessa prática levou também revistas e jornais de grande circulação a noticiarem o surgimento de mais um movimento juvenil" (ALFONSI, 2007, p.50).

O forró "Pé de Serra" permanece no meio sociocultural, até os dias atuais. Ele é dançado em pares, em que a dama é conduzida pelo cavalheiro. Inicia-se em um passo básico e durante a dança ocorrem giros, movimentos variados com pés e pernas; movimentação do quadril, principalmente realizada pela dama. As musicas antigas e

\footnotetext{
${ }^{4}$ TRINDADE, M. Iso aqui tá bom demais: festas populares que reúnem milhões de pessoas, vendas milionárias de discos e ciclo de shows demonstram o vigor do forró, um gênero que atravessa gerações. Bravo!, São Paulo, v 7, n.81, p.52-57, jun. 2004
} 
tradicionais, voltadas para o cenário nordestino, ainda são muito tocadas, além de canções atuais e outras presentes em diferentes ritmos e gêneros musicais. Hoje, o forró mistura-se principalmente com o Reggae e com o MPB; canções que estão presentes na voz de Bob Marley, Banda Planta e Raiz, Zeca Baleiro, Mariza Monte, Lenine, Maria Rita, entre outros. As canções são cantadas e tocadas no ritmo e com os instrumentos componentes do forró "Pé de Serra". Essa mistura, como uma das transformações do forró na atualidade, mostra ainda mais, o quanto ele se inova e permanece culturalmente na sociedade sem perder sua essência. Portanto, ele deixou de ser um simples "boom" e se transformou numa manifestação cultural alternativa que abrange um público fiel e com características específicas, no entanto, não é comum ouvir o forró "Pé de Serra" nas rádios ou assistir uma banda tocá-lo na TV.

Os espaços alternativos do forró em BH (casas noturnas), localizam-se em sua maioria, na zona sul da cidade. Geralmente o forró acontece nas quartas, quintas, sextasfeiras e aos domingos. Durante a semana, iniciam-se mais tarde, por volta das $23 \mathrm{hs}$. Aos domingos mais cedo, em torno das 19hs. Nesses espaços, costuma-se oferecer aulas de forró ou dança de salão. Eles são freqüentados, principalmente, por um público jovem.

Os shows de cantores (as), trios ou bandas de forró, ocorrem nas próprias casas alternativas e não necessitam de um espaço amplo para se concretizar, pois nos shows não se observa uma “multidão de pessoas". Em sua maioria, são marcados pela presença de jovens que realmente apreciam a beleza e o encanto do forró "Pé de Serra".

\section{O jovem...}

“A juventude é uma etapa do desenvolvimento com características singulares, que apresenta mudanças no físico e no psiquismo; estado de espírito que torna tudo 
permitido" (GRINSPUN, 2007, p. 9).

Na década de 90 a juventude era vista como um problema social, envolvendo drogas, tráfico, violência, gravidez entre outros. Posteriormente, em 2000, organizações não governamentais- ONGs e fundações empresariais do terceiro setor passam a apoiar projetos de valorização de expressão cultural de jovens como forma de sociabilidade, com a finalidade instrumental de inclusão social, redução da violência ou geração de emprego. A atuação dessas organizações e agências contribuiu para trazer o jovem à cena pública, dando destaque e relevância aos segmentos juvenis. Em muitos casos, esses projetos se apoiaram na concepção do jovem enquanto protagonista, como agente de transformação (VILUTIS, 2009, p.35).

Quanto à faixa etária, a juventude se apresenta entre os 15 aos 29 anos de idade, podendo se estender para baixo ou para cima, tendo seu limite máximo dos 12 aos 35 anos de idade (LEÓN, 2005). Sociologicamente, o fim da juventude apresenta as seguintes características: terminar os estudos; viver do próprio trabalho; sair da casa dos pais e estabelecer-se numa moradia pela qual seja responsável ou co-responsável; casar; ter filhos. Porém, essas condições não bastam para caracterizar o termo “jovem”. Essas condições podem ser relativas e, portanto, não dão conta de caracterizar a condição juvenil (LEÓN; ABRAMO, 2005). A juventude não é um “dom” que se perde com o tempo, e sim uma condição social com qualidades específicas que se manifesta de diferentes maneiras segundo as características históricas sociais de cada indivíduo (BRITO 5 apud LEÓN, 2005, p.13). Portanto, a juventude pode apresentar diversos significados, não se restringindo necessariamente e somente a faixa etária e sim se ampliando a questões sociais, históricas e culturais de cada individuo. Neste contexto,

\footnotetext{
${ }^{5}$ BRITO, Roberto Lemus. Hacia una sociología de la juventud. JOVENES, Revista de Estudios Sobre Juventud, nº1. México: IMJ, 1996.
} 
Luana Vilutis mostra o conceito sobre a juventude abordado no documento de

Conclusão do Projeto Juventude, realizada pelo Instituto Cidadania:

A condição juvenil é dada pelo fato de os indivíduos estarem vivendo um período específico do ciclo de vida, num determinado momento histórico e cenário cultural. No contexto atual, juventude é, idealmente, o tempo em que se completa a formação física, intelectual, psíquica, social e cultural, processando-se a passagem da condição de dependência para a de autonomia em relação à família de origem. A pessoa torna-se capaz de produzir (trabalhar), reproduzir (ter filhos e criá-los), manter-se e prover a outros, participar plenamente da vida social, com todos os direitos e responsabilidades. Portanto, trata-se de uma fase marcada centralmente por processos de definição e de inserção social. [...] A condição juvenil não pode mais ser compreendida como apenas uma fase de preparação para a vida adulta, embora envolva processos fundamentais de formação. Ela corresponde a uma etapa de profundas definições de identidade na esfera pessoal e social, o que exige experimentação intensa em diferentes esferas da vida (INSTITUTO CIDADANIA, 2004, p. 10).

Diante da dimensão de significados da palavra "juventude" não podemos negar que o jovem busca sua identidade e, portanto, ele cria ou se insere em determinado grupo social. Lomônaco e outros (2008, p.14) acreditam que [...].

[...] fazer parte de um grupo é algo essencial para a vida dos jovens. Alguns buscam apenas pertencer a uma turma de amigos sem uma denominação própria. Outros escolhem fazer parte de uma tribo[...] as tribos reforçam um sentimento de pertencimento e favorecem uma nova relação com o ambiente social.

Ele se encontra ao identificar-se com: estilos de roupas, cabelo e acessórios, além músicas, crenças, culturas, valores, costumes. Então, é possível observar que a construção do grupo social dos forrozeiros é formada por "jovens" que, de alguma forma identificaram-se com o dançar, ouvir e freqüentar o forró. Estes forrozeiros são jovens que possuem responsabilidades com o trabalho, com o estudo e com a família, mas que também possuem seus desejos e sonhos. Eles precisam da ludicidade, ou seja, a liberdade de ser e o prazer de viver. Esta experiência é possibilitada em seus momentos 
de lazer pela opção de vivenciar o forró "Pé de Serra".

O forró é marcado por misturas culturais. Isso se vê presente nas letras musicais, na dança, nas características das bandas, nos instrumentos e na caracterização do próprio forrozeiro. Essa diversidade cultural se reconstrói, adquiri novos valores e características; transforma-se, envolvendo principalmente a participação do público jovem como sujeito transformador.

O início da formação de um grupo jovem dedicado ao forró "Pé de Serra" tem como base, como vimos anteriormente, a migração dos nordestinos para o sudeste brasileiro na década de 40 . O forró se propagou na década de 50, principalmente, através da rádio. No final da década de 60, Luiz Gonzaga aparece com o termo "forró" e, nesse mesmo período ocorre á aproximação dos jovens da classe média da sociedade com a cultura popular. Esses jovens passam a reverenciar o cantor, defendendo a música relacionada aos movimentos de protestos. O trabalho de jovens dramaturgos e poetas ganha destaque (SILVA, 2003). Em 1999, o Instituto Brasileiro de Geografia e Estatística (IBGE) apresentou dados estatísticos referentes à população jovem na região Sudeste. Eles comprovam a migração dos jovens nordestinos, uma movimentação que levou o forró aos jovens "sudestinos".

Regionalmente, merece destaque o fato de que a população jovem (grupo de 15 a 24 anos de idade) experimentou uma retomada em seu ritmo de crescimento nas Regiões Sudeste e Sul entre os períodos de 1980-1991 e 1991-1996, o suficiente para repercutir no nível nacional. A distribuição dos jovens pelas Grandes Regiões brasileiras mostrou que a Região Sudeste perdeu representatividade entre 1980 e 1996, enquanto que a Nordeste galgou percentuais, em função de uma provável retenção de migrantes potenciais aliada a uma migração de retorno proveniente, sobretudo do Sudeste. Com relação à situação de residência da população jovem, a Região Sudeste historicamente apresenta as maiores proporções de jovens residindo em áreas urbanas, seguida da Região Centro-Oeste. Mas a tendência geral de evolução é de aumento nestas proporções em todas as Grandes Regiões (INSTITUTO BRASILEIRO DE GEOGRAFIA E ESTATÍSTICA, 1999). 
Mesmo com o provável retorno dos jovens migrantes para sua terra natal, o sudeste é tomado por jovens que tem como propósito, se encontrarem. A cultura nordestina torna-se mais uma opção para o jovem conhecer novas pessoas, dançar, namorar, se permitir. È mais um grupo social para ele inserir-se. Nesse momento o forró ganha destaque num novo cenário; nas metrópoles do sudeste brasileiro. Surgem bandas de forró, espaços dedicados à dança e música do forró "Pé de Serra" e a forte imagem da cultura nordestina na produção do jovem.

Com o tempo, o forró é abraçado por quem realmente o admira. Atinge um público, em sua maioria jovem e fiel. Atualmente, os jovens forrozeiros tornam-se um grupo social alternativo. Eles se encontraram na dança, na música e no ritmo do forró "Pé de Serra". Eles são únicos e reconhecíveis. As meninas usam roupas mais soltas (saias, calças, vestidos) e no pé as sapatilhas chinesinhas ou sandálias "rasteiras"; de couro ou trançadas nas pernas. Os meninos usam bermuda ou calça; tênis confortável, o famoso chinelo de couro ou simplesmente as havaianas. Além disso, os acessórios femininos chamam muita atenção, como: cintos, pulseiras, anéis de coco, colares feitos de sementes, tornozeleiras, brincos de penas e as cartucheiras ${ }^{6}$.

\section{A motivação...}

A motivação é a força interna que emerge, regula e sustenta todas as nossas ações. Ela é estudada indiretamente, portanto, analisada a partir do comportamento humano. O comportamento humano pode ser irracional ou racional (VERNON, 1973).

O comportamento irracional está relacionado com as questões de sobrevivência (fuga e medo; repulsão e repugnância; curiosidade e espanto; combatividade e ira; auto-

\footnotetext{
${ }^{6}$ Bolsa em forma de cinto, num estilo que lembra os cangaceiros do século passado no Brasil, usada por cima da calça, saia ou short para guardar objetos e documentos.
} 
degradação e sujeição; auto-afirmação e orgulho; instinto paternal e ternura; reprodução e desejo sexual). Por sua vez, o comportamento racional está relacionado à plena consciência do homem diante de suas ações, com objetivo definido e direção guiada pelo pensamento (FLETCHER ${ }^{7}$ apud VERNON, 1973).

Até os primeiros anos do século $\mathrm{XX}$, a teoria mais popular da palavra "motivação", era a denominada hedonismo psicológico, que significa a procura do prazer (VERNON,1973). “A motivação tipicamente dirige o comportamento para um determinado incentivo que produz prazer ou alivia um estado desagradável" (ATKINSON et al., 2002, p.372). Esse "prazer" está associado à emoção e aos sentimentos que movem e envolvem o homem antes, durante e após a ação, proporcionando-lhe sensações prazerosas e incentivando-o a querer vivenciá-la novamente. No presente estudo, não será possível falar de motivação sem considerar as emoções e os sentimentos, pois estamos lidando com o jovem (ser que possui essas "virtudes da vida" muito bem afloradas) e do forró "Pé de Serra" (prática que desperta as emoções com suas canções, ritmos e gingado da dança).

As emoções são:

[...] expressões afetivas acompanhadas de reações intensas e breves do organismo, em resposta a um acontecimento inesperado ou, às vezes, a um acontecimento muito aguardado (fantasiado) e que, quando acontece[...] são fortes e passageiras, intensas, mas não imutáveis (BOCK, FURTADO, TEIXEIRA, 2002, p.194-197).

Os sentimentos por sua vez, também estão relacionados ao afeto, mas "diferem das emoções por serem mais duradouros, menos explosivos e por não virem acompanhados de reações orgânicas internas" (BOCK, FURTADO, TEIXEIRA, 2002,

\footnotetext{
${ }^{7}$ FLETCHER, R. Instinct in man. London, Allen e Unwin, 1957.
} 
p. 198).

As reações emocionais e sentimentais, como fatores motivadores do ser humano, estão intensamente presentes no forró. Isso porque o som e as letras das músicas fazem com que os jovens despertem seus sentimentos: o amor, a ternura, a amizade; fazem despertar as emoções: o coração bate mais forte, o suor toma conta da pele, acontece um arrepio no corpo, os rostos refletem uma expressão de felicidade, paixão e desejo. As músicas remetem a um mundo de sonhos e realidades; desejos e dificuldades; letras que inspiram aventuras; um mundo de alegria, chamego, balanço, saudade, paixão e amor... aquilo que o jovem sente de mais forte...aquilo que mexe com ele. Muitas músicas cantam o envolvimento, o contato, a relação e o afeto com o outro. Como por exemplo,

\title{
De rosto colado:
}

\author{
Quando olho nos seus olhos eu sinto \\ Uma vontade louca de beijar sua boca \\ Seu beijo é doce feito mel \\ È uma felicidade que chega \\ Zumbando meu peito, deixando sem jeito \\ Esse meu coração \\ Tu eis minha flor \\ Linda como o sol ardente no verão \\ É só parar e perceber \\ Que eu estou te amando \\ Tão linda flor, tão bela flor \\ Beleza da cor morena me faz viajar \\ Vem fazer parte de mim \\ Vou lhe mostrar que a vida é melhor \\ Quando estás comigo amor \\ Quero dormir ao seu lado \\ E de rosto colado, acordar com você (TRIO ALVORADA)
}

Além das emoções e dos sentimentos, que fazem parte da motivação intrínseca do individuo e que envolvem os jovens e os levam a vivenciar o forró, há também motivos extrínsecos que podem levá-los á praticar essa manifestação. Para Bock, Furtado e Teixeira (2002), o estudo da motivação é constituído por três variáveis: o ambiente, as forças internas do individuo e o objeto. Neste contexto, os fatores 
ambientais são dados: pelo local onde se dança o forró (casas alternativas ou escolas de dança que se ouve e se dança o forró "Pé de Serra"), pelas pessoas que o compõe (seja do convívio do jovem ou não) e por tudo que caracteriza o grupo social dos forrozeiros (acessórios, roupas, sapatos, costumes e cultura), ou seja, são representados pelos fatores externos do meio. Já os fatores das forças internas do individuo é dado pelos seus sentimentos, emoções, desejos, interesses, impulso ou instinto; neste caso pode aflorar, no jovem forrozeiro sentimentos e emoções que fazem com que ele admire e vivencie a dança e a música; sentindo então o prazer, o amor, a atração, o bem estar e a alegria de praticá-la. Finalmente o fator objeto, que é representado, inevitavelmente, pelo o forró "Pé de Serra".

Com base nas variáveis que fazem parte da motivação é questionável que os jovens busquem o mesmo objetivo, porém podem ter motivos diferentes para buscá-lo. Assim, com a diversidade de interesses existentes entre os indivíduos permite que as pessoas não façam as mesmas coisas pelas mesmas razões (BERGAMINI ${ }^{8}$ apud BANDEIRA, 2008). Portanto, o que move um jovem a praticar o forró "Pé de Serra" pode não ser o que move o outro. Partindo desta ideia, o estudo desse trabalho quer verificar quais são os principais fatores que de forma mais intensa "chamam" os jovens para viver e reviver o forró. Momento este, que os jovens estão à procura da sua identidade e em busca de emoções.

"A identidade é a denominação dada às representações e sentimentos que o individuo desenvolve a respeito de si próprio, a partir do conjunto de suas vivências" (BOCK, FURTADO, TEIXEIRA, 2002, p.145). Assim, ao vivenciar e identificar com o forró, o jovem faz a descoberta de mais um fator que o leva à construção de sua

\footnotetext{
${ }^{8}$ BERGAMINI, Cecília Whitaker. Motivação. 3. ed. São Paulo; Atlas, 1990.
} 
identidade. Então, é o momento em que ele se reconhece, sente-se à vontade, tem prazer. Esta identidade é construída pelos fatores motivadores, pelo que o leva a dançar, ouvir, cantar e vivenciar o forró. Como diz na música Saudade de Itaúnas: “sem saber pra onde ir, sem saber onde ficar... eu encontrei um lugar pra me encontrar..." e assim, quando o jovem se "encaixa" numa cultura e num prazer que se torna prática fundamental em sua vida, ele se identifica para si mesmo e para sociedade... no caso dos jovens deste estudo, tornam-se "forrozeiros".

\section{METODOLOGIA E RESULTADOS}

A pesquisa bibliográfica foi fundamental para dar inicio ao trabalho. Ela foi à base para que fosse possível definir o forró "Pé de Serra", o jovem e a motivação. Posteriormente, foi necessária uma pesquisa de campo, na qual ocorreu uma observação participante para a descrição do local (espaço alternativo) e dos jovens forrozeiros analisados na pesquisa. Portanto, por meio da observação, foi possível analisar o comportamento, práticas, hábitos, costumes e valores dos jovens. Além da observação participante foram aplicados questionários, cada um com nove questões. Para respondê-los, foram escolhidos aleatoriamente 20 jovens; 10 deles mulheres e 10 homens. Por meio da observação e dos questionários, foi possível analisar o comportamento e o significado do forró "Pé de Serra" para cada um deles, remetendo a algumas diferenças e igualdades do que os motivam a dançar e freqüentar o forró. Com isso, foi verificada qual a motivação que se apresenta de forma mais marcante na vida dos jovens, fazendo-os viver e reviver o forró "Pé de Serra".

\footnotetext{
${ }^{9}$ Música da Banda "O bando de Maria".
} 


\section{O espaço alternativo...}

O espaço observado é tipicamente uma casa noturna, como já descrita anteriormente. Localiza-se na Zona Sul da Cidade, região em que reside a maior parte da alta classe social de $\mathrm{BH}$ e onde também se encontra o maior número de equipamentos de lazer. No local, o forró "Pé de Serra" é ouvido e dançado especificamente aos domingos. Inicia-se por volta das 19:30 e seu término é por volta das 01:30 da manhã.

Do lado de fora, antes do horário previsto para seu início, é formada uma fila. Por questões legais, apenas maiores de 18 anos entram. O local fica bastante cheio, principalmente em dias de shows. A decoração remete a fantasias, ao meio rural, ao rústico e tradicional. Ao olhar para o teto, são observados alguns objetos de madeira pendurados. As mesas e a estrutura do local também são predominantemente de madeira. Além disso, existem alguns objetos antigos que ajudam a enfeitar o local como, por exemplo, uma máquina de escrever próxima a uma escada existente no espaço. Também são encontradas flores e retalhos de tecidos, usados para alegrar o ambiente.

No espaço vendem-se bebidas (cerveja, refrigerantes, xiboca $^{10}$ e catuaba) e há um pequeno palco, onde ficam o $\mathrm{Dj}$, cantor (a), banda ou trio. Quando não ocorrem os shows os Djs tocam, nas caixas de som, o forró "Pé de Serra"; canções que remetem ao cenário nordestino, aos sentimentos e emoções, além das que fazem parte de outros gêneros musicais e são tocadas no ritmo do "Pé de Serra". Dentre elas, a música "Segue o Seco" leva muitos forrozeiros a pista de dança. Ela lembra o cenário nordestino,

${ }^{10}$ Bebida alcoólica feita da mistura da pinga, gengibre canela e mel. 
porém faz parte do gênero musical MPB.

\author{
A boiada seca \\ Na enxurrada seca \\ A trovoada seca \\ $\mathrm{Na}$ enxada seca \\ Segue o seco sem secarque o caminho é seco \\ sem sacar que o espinho é seco \\ sem sacar que seco é o Ser Sol \\ Sem sacar que algum espinho seco secará \\ E a água que sacar será um tiro seco \\ E secará o seu destino seca \\ Ô chuva vem me dizer \\ Se posso ir lá em cima prá derramar você \\ Ó chuva preste atenção \\ Se o povo lá de cima vive na solidão \\ Se acabar não acostumando \\ Se acabar parado calado \\ Se acabar baixinho chorando \\ Se acabar meio abandonado \\ Pode ser lágrimas de São Pedro \\ Ou talvez um grande amor chorando \\ Pode ser o desabotado do céu \\ Pode ser coco derramado (Carlinhos Brown).
}

Nos momentos finais da noitada, a casa encontra-se vazia. Assim, os jovens que restaram, aproveitam o espaço vazio para dançar com mais giros, mais "remelexos" e sem a preocupação de trombar em outro casal, nas mesas de madeira ou em outros objetos.

\title{
Os jovens forrozeiros de Belo Horizonte...
}

Aparentemente, o público frequentador das "noitadas" do forró "Pé de Serra" é, predominantemente, jovem. Os jovens se apresentam alegres e envolvidos com a música e com a dança; vão bem caracterizados: meninas com saias, vestidos, roupas mais soltas e sandálias ou sapatilhas nos pés; os meninos com calças ou bermudas, com chinelos ou tênis. Também se vê os colares e pulseiras de sementes, tornozeleiras; brincos de concha, pena e madeira. Parece que as bolsas foram descartadas no forró, 
raramente observa-se alguém com a famosa cartucheira ou com as pequenas bolsas, de alça longa, atravessadas no ombro.

No espaço, observa-se que, em sua maioria, são as mesmas pessoas que o frequentam toda semana e existem "pequenas turminhas" de amigos, as chamadas "panelinhas". Quando eles não estão conversando, estão à espera de um convite para dançar.

É perceptível o quanto eles se envolvem com a dança e com a música. Alguns ouvem e cantam, de olhos fechados; outros, de olhos fechados, dançam...envolvem-se no contato com o outro. Outros ainda trocam ideias e conversam com a "galera" da turma, tomando alguma bebida. A xiboca e a catuaba são as mais vistas.

Ao aplicar os questionários houve um fato surpreendente o qual eu não havia reparado antes: os jovens forrozeiros são, em sua maioria, jovens adultos, ou seja, aqueles que estão numa faixa etária que alcança os 35 anos de idade (como mencionado anteriormente neste trabalho). Descobri que é realmente difícil encontrar um jovem no forró que tenha menos que 21 anos de idade. Por isso a faixa etária dos participantes foi definida com base na observação e na idade dos respondentes dos questionários.

Dos jovens respondentes, apenas dois deles são casados, o restante, solteiros. Eles moram em diferentes regiões da cidade de Belo Horizonte, não aparecendo nenhuma região específica que tenha uma quantidade maior de residentes jovens forrozeiros, apesar da casa noturna se localizar na zona sul da cidade. Assim, presumi-se que jovens de várias regiões de $\mathrm{BH}$ frequentam o local, desde as mais próximas do espaço até as mais distantes, como por exemplo, os que residem na zona norte. Quanto ao tempo, em sua maioria, frequentam e praticam o forró "Pé de Serra" há aproximadamente cinco anos. Essa alternativa foi selecionada por quatorze jovens. 
Além disso, em sua maior parte, são jovens estudantes ou concluintes do ensino superior. Desses, nove possuem ensino superior incompleto e sete possuem ensino superior completo, apenas quatro deles possuem somente o ensino médio completo.

Partindo da ideia de que cada ser humano, jovem ou não, vê e sente o mundo do seu jeito e que tudo flui do seu pensamento, conhecimento e percepção... alguns jovens escreveram no questionário, uma frase do que o forró representa para eles, do que remete essa vivência de dançar, ouvir e sentir o forró "Pé de Serra":

O forró é meu refúgio, um lugar onde o mundo treme e eu fico firme/ É um vício que faz bem / É minha paixão/ É deixar se levar pelas músicas/ É um momento que esqueço meus problemas/ Faz o corpo arrepiar e o coração bater mais forte/ Traz leveza à alma/ É o momento de curtir o meu dia fazendo o que realmente gosto/ É o prazer de ouvir, sentir e dançar...

Apesar dessa percepção única de cada ser humano, dos jovens forrozeiros participantes deste estudo, dezessete deles interessaram-se pela vivência do forró por meio da observação da dança e da música, nove devido a influencias de outras pessoas que já freqüentavam o forró, três por causa de lugares que ouviam e dançavam o forró (seja escola de dança ou casa noturna), dois por causa de roupas e acessórios dos forrozeiros. Apenas um deles se interessou por influencias da rádio e da TV e um se interessou devido a influências familiares.

Quanto ao motivo pelo qual eles buscam reviver o forró, dezessete jovens afirmam que o ritmo mexe com os sentimentos e emoções, seis por gostarem dos "ambientes alternativos", quatro porque pessoas do seu convívio freqüentam e três buscam a prática do forró para conhecer novas pessoas e novos lugares.

Quanto ao significado de "dançar" o forró, dezessete jovens o consideram como 
uma prática de lazer/ prazer, sete afirmam ser uma diversão e "balada"11, sete acreditam ser uma encontro com os amigos, quatro afirmam ser uma atividade física e dois acreditam ser uma manifestação cultural.

A partir desses resultados, será discutida e concluída qual a motivação dos jovens forrozeiros de $\mathrm{BH}$, tendo em vista a observação deles, dentro do espaço alternativo e, principalmente do que os motivam a viver e dar continuidade a essa vivência.

\section{CONSIDERAÇÕES FINAIS: A MOTIVAÇÃO DOS JOVENS PARA VIVER E REVIVER O "PÉ DE SERRA"}

Por meio desse estudo, percebe-se que a motivação abrange uma dimensão ampla e dependente de fatores internos e/ou externos para manifestar-se. Foi possível diagnosticar a força da manifestação das emoções e dos sentimentos quando os jovens "vivem" o forró "Pé de Serra". São reações internas incontroláveis, que os permitem: sorrir, chorar, amar, apaixonar, "chamegar", enfim... emocionar. O forró torna-se um momento único de esquecer os problemas, de viver como se fosse a última vez, de fazer com que se queira reviver aquela experiência novamente. Alceu Valença mostra numa de suas músicas o quanto o homem ilude-se, ao achar muitas vezes, que "o coração" não tem valor em seu comportamento, porém é ele que define muitas vezes nossas respostas a favor do amor, da compreensão, do perdão... é ele que age impulsivamente, sem controle, sem direção e sem permissão. O cantor chama de "Coração bôbo":

Meu coração tá batendo Como quem diz não tem jeito

Zabumba, bumba esquisito

${ }^{11}$ Noitada em que as pessoas saem para dançar, conversar, beijar e conhecer outras pessoas. 
Batendo dentro do peito

Teu coração tá batendo

Como quem diz não tem jeito

O coração dos aflitos

Batendo dentro do peito

Coração bobo, coração bola

Coração balão, coração São João

A gente se ilude dizendo

Já não há mais coração (ALCEU VALENÇA, 1980).

Portanto, talvez seja pela força incontrolável das emoções e dos sentimentos, que os jovens forrozeiros têm como motivação principal o envolvimento intrínseco com as músicas e com a dança do forró "Pé de serra". Essa motivação traz prazer e leveza ao corpo e a alma desses jovens. No entanto, percebe-se também, a importância do meio externo na construção da identidade e na presença do prazer, por meio da vivência do forró "Pé de Serra", na vida dos jovens forrozeiros. Assim, sem os fatores externos (o ritmo e letras das canções, envolvimento com o outro na dança, clima e visualização do ambiente ou, até mesmo, roupas e acessórios) seria impossível que os jovens sentissem o amor, o chamego, a paixão, o acelerar do coração, o arrepio do corpo e o prazer de viver o forró. Então, verifica-se a importância da interação do homem com o meio para que o corpo possa falar, sentir e expressar a necessidade de viver novamente a experiência.

Ser jovem e ser forrozeiros: é aventurar-se; é se encontrar e descobri quem realmente você é, é entregar-se ao que realmente admira; é ter coragem para afirmar-se na sociedade e caminhar em busca dos seus objetivos e ideais; é ser, viver e buscar prazer através da sensibilidade dos sentimentos e emoções. Portanto, foi possível perceber, em cada jovem pesquisado, a importância: do meio social, da vivência com o ambiente agradável, da relação com outras pessoas, dos acessórios e roupas que os deixam á vontade e, principalmente, do envolvimento emotivo e sentimental quando 
ouvem ou dançam o forró... o som e o ritmo tocam, de forma mais intensa e marcante, os corações desses jovens. Eles expressam o prazer que vem "de dentro". Essa vivência é tão boa que os fazem reviver a experiência de viver o forró, como disseram alguns jovens pesquisados: "é um vício", um "refugio", uma "paixão". Neste contexto, o forró "Pé de serra" se torna uma alternativa de lazer para esses jovens, faz bem ao corpo físico e psicológico. Ele é um meio cultural, social e histórico que estimula a educação e o respeito através da relação com o outro, ativa as reações fisiológicas importantes para um bom funcionamento do organismo (o batimento acelerado do coração, sudorese, aumento da circulação sangüínea...) e promove a motivação intrínseca não somente para a vivência do forró, mas também para a vida afetiva, familiar, profissional e pessoal, pois, o forró leva-lhes o bem estar, prazer, harmonia, felicidade...proporcionando-lhes autoestima, vontade de viver. Com o forró eles se encontram, permitem-se, sentem a necessidade pelo prazer de ser e viver o "Pé de Serra".

Concluindo, Bergamini ${ }^{12}$ citado por Bandeira (2008), relata que tanto os comportamentos condicionados quanto os incondicionados exigem alguma necessidade ativa intrínseca para se realizarem de forma enérgica, motivando o comportamento. Então, considera-se que a motivação dos jovens forrozeiros é envolvida por vários fatores que compõe o forró, fazendo surgir prioritariamente os fatores intrínsecos, que despertando sentimentos e emoções e que os motivam a viver e reviver essa experiência.

${ }^{12}$ BERGAMINI, Cecília Whitaker. Motivação. 3. ed. São Paulo; Atlas, 1990. 


\section{REFERÊNCIAS}

ALFONSI, Daniela do Amaral. O forró Universitário em São Paulo. IN: MAGNANI, José Guilherme Cantor; SOUZA, Bruna Mantese de (Org.).Jovem na Metrópole: etnografias de circuitos de lazer, encontro e sociabilidade. São Paulo: Terceiro nome, 2007. p. 42-65.

ATKINSON, Rita L. et al. Introdução à psicologia de Hilgard. 13. ed. Porto Alegre: Artmed, 2002. 372p.

BANDEIRA, Benna. Motivação: um fator fundamental para a aprendizagem. Recanto das letras, 2008. Disponível em: http://www.recanto das letras.com.br/artigos. Acesso em: 28 dez. 2011.

BOCK, Ana Mercês Bahia.; FURTADO, Odair.; TEIXEIRA, Maria de Lourdes Trassi. Psicologias: uma introdução ao estudo de psicologia. 13. ed. São paulo: Saraiva, 2002. $368 \mathrm{p}$.

BROWN, Carlinhos. Segue o seco. In: MONTE, Marisa. Barulhinho bom. Faixa10. CD player. Disponível em: <http://www2.uol.com.br/marisamonte/novosite/novositeport.htm>. Acesso em: 08 nov. 2010 .

CORTÊS, Gustavo Pereira. Dança Brasil: festas e danças populares. Belo Horizonte: Editora Leitura, 2000. 186p.

DE ROSTO COLADO. Disponível em: http://letras.terra.com.br/trioalvorada/1497819 .Acesso em: 22 nov. 2010.

FONSECA, João José Saraiva da. Metodologia da pesquisa cientifica. Universidade estadual do Ceará, 2002. 127p. Disponível em: 〈http://books.google.com.br〉. Acesso em: $21 \mathrm{dez} .2011$.

GORDURINHA; GONZAGA, Luis. Súplica Cearense. In: GONZAGA, Luis. Maxximum. lugar: Sony, 2005. Faixa 16. CD player.

GRINSPUN, Miriam Paura Sabrosa Zippin. Juventude: uma luz que transcende o olhar. Rio de Janeiro: 7 Letras, 2007. 88p.

HUIZINGA, Johan. Homo Ludens: o jogo como elemento da cultura. 5. ed. São Paulo: Perspectiva, 2001. 243p.

$\begin{array}{llll}\text { INSTITUTO BRASILEIRO DE GEOGRAFIA E ESTATÍSTICA. População jovem } \\ \text { do } & \text { Brasil. } & 1999 . & \text { Disponível }\end{array}$ <http://www.ibge.gov.br/home/estatistica/populacao/populacao_jovem_brasil/default.sh tm> Acesso em: 26 ago. 2010.

INSTITUTO CIDADANIA. Projeto Juventude: documento de conclusão. São Paulo, 2004. 
JUNIOR, Antonio C. de Quadros. et al. Caracterização do xote e do Baião dançados no interior do Estado de São Paulo. Revista Movimento. Porto Alegre, v.15, n.03, p.233247, jul/set. 2009.

JUNIOR, Carlos de Quadros;VOLP, Catia Mary. Forró universitário: a tradução do forró nordestino no sudeste brasileiro. Revista Motriz. Rio Claro,v.11,n.2, p.117-120, mai/ago. 2005.

LANCELLOTTI, Julio Renato. O jovem: a imagem nas telas nas ruas. In: DIDONÉ, Iraci Maria; SOARES, Ismar de Oliveira (Org.). Jovem e a Comunicação: leitura do mundo, leitura de si. São Paulo: Loyola, 1992. p. 11-14.

LEÓN, Oscar Dávila.; ABRAMO, Helena Wendel. Juventude e Adolescência no Brasil: referências conceituais. São Paulo : ação educativa, p. 5-35, nov. 2005. Disponível em: <http://www.uff.br/emdialogo/sites/default/files/caderno_juventude_e_adolescencia_no _brasil_0.pdf > Acesso em: 26 dez. 2011.

LOMÔNACO, Beatriz Penteado et al. Mundo jovem. São Paulo: Fundação Tide Seterbal, 2008. 179p.

MALINO, Kuque. Inovação. In: ESTAKAZERO. Lua minha. Leke, 2005. Faixa 01. CD player.

MARCELLINO, Nelson Carvalho. Lazer e Educação. São Paulo: Papirus, 1987. 144p.

PROJETO FORRÓ BH. Disponível em: <http://www.portalpedeserra.com.br/blog/sobre> Acesso em: 11 out. 2010.

SANTOS, José Faria dos. Luis Gonzaga: a música como expressão do Nordeste. São Paulo: Ibrasa, 2004. 208p.

SAUDADE DE ITAÚNAS. Disponível em: <http://www.letras.terra.com.br/obandodemaria> Acesso em: 13 out. 2010.

SILVA, Expedito Leandro. Forró no asfalto: mercado e identidade sociocultural. São Paulo: Annablume/Fapesp, 2003. 153p.

SILVA, João; AQUINO, J.B. de. Jerimum de Gogo. In: Marinês. Siu,siu,siu. 1964. Faixa $08 . \quad$ CD player. Disponível em: <http://www.cantorasdobrasil.com.br/cantoras/marines.htm> Acesso em: 02 de set. 2010.

TEIXEIRA, Humberto; GONZAGA, Luiz. Baião. Rádio batuta: Instituto Moreira Sales. 1949. Disponível em: < http://homolog.ims.com.br/cgi-bin/wxis.exe/iah/ > Acesso em 10/11/2010.

VALENÇA, Alceu. Coração bobo. In: VALENÇA, Alceu. Coração bobo. Ariola, 1980. Faixa1. Disco de Vinil. Disponível em: <http://www.alceuvalenca.com.br> Acesso em: 08 nov. 2010. 
VERNON, Magdalen Dorothea. Motivação Humana: a força interna que emerge, regula e sustenta todas as nossas ações. Petrópolis. Rio de Janeiro: Vozes, 1973. 303p.

VILUTIS, Luana. Cultura e juventude: a formação dos jovens nos pontos de cultura. 2009. Dissertação (Mestrado) - Faculdade de Educação, Universidade de São Paulo, São Paulo, 2009.

\section{Endereço da Autora:}

Camila Mourão Cardilo

Rua Augusto César dos Santos, n²0

bairro Letícia, BH-MG

CEP:31570210

Endereço Eletrônicocamilacardilo@ hotmail.com 